\title{
Pengembangan Model Pembelajaran Sejarah Kepemimpinan Berbasis Pedagogi Reflektif Untuk Meningkatkan Sikap Kepemimpinan Siswa SMA
}

\author{
Yoel Kurniawan Raharjo* \\ Universitas Sanata Dharma \\ *Corresponding author`s e-mail: yoelkurniawan@usd.ac.id
}

\begin{abstract}
History learning has a strategic function in developing the character values of students if the teacher teaches innovatively. Viewing philosophical pedagogy, history is not only a means of transmitting knowledge but also transmitting value and transmitting virtue. The design of history learning should not only explore the narrative of events, but be able to reflect the character values of the material being studied. Historical material about heroism contains character values, one of which is leadership. Leadership values can be taught to students in order to foster leadership attitudes. This study aims to develop a historical learning model based on reflective pedagogy to improve students' leadership attitudes. This learning model is integrated in KD 3.2 sub material Struggle RM Said or Mangkunegara I. The research method uses development research. The object of the research is the students of Class XI Social Studies SMA Kolese De Britto, Yogyakarta. The results of the study show that (1) leadership attitudes among students need to be improved as seen from the 8 leadership indicators from Northouse and Ignatian, (2) teachers are still only focused on exploring historical events narratives because they are fixated on dictates, and (3) Development of learning models This history is effective to improve students' leadership attitude with normality test, homogeneity test, and $t$ test.
\end{abstract}

Keywords: historical; reflective pedagogy; leadership attitude

Abstrak: Pembelajaran sejarah memiliki fungsi strategis dalam mengembangkan nilai karakter peserta didik apabila guru mengajarkan secara inovatif. Meninjau filosofis pedagogik, sejarah bukan hanya sebagai sarana transmitting knowledge namun juga transmitting value dan transmitting virtue. Desain pembelajaran sejarah sebaiknya bukan hanya mengeksplorasi narasi peristiwa saja, tetapi mampu merefleksi nilai karakter dari materi yang dipelajari. Materi sejarah tentang heroisme mengandung nilai karakter, salah satunya kepemimpinan. Nilai kepemimpinan dapat diajarkan kepada peserta didik dalam rangka menumbuhkan sikap kepemimpinan. Penelitian ini bertujuan mengembangkan model pembelajaran sejarah berbasis pedagogi reflektif untuk meningkatkan sikap kepemimpinan siswa. Model pembelajaran ini diintegrasikan dalam KD 3.2 sub materi Perjuangan RM Said atau Mangkunegara I. Metode penelitian menggunakan penelitian pengembangan. Objek penelitian adalah peserta didik Kelas XI IPS SMA Kolese De Britto, Yogyakarta. Hasil penelitian menunjukan bahwa (1) sikap kepemimpinan dikalangan peserta didik perlu ditingkatkan dilihat dari 8 indikator kepemimpinan dari Northouse dan Ignatian, (2) guru masih berkutat pada eksplorasi narasi peristiwa sejarah saja karena terpaku pada diktatdiktat, serta (3) Pengembangan model pembelajaran sejarah ini efektif untuk meningkatkan sikap kepemimpinan siswa dengan uji normalitas, uji homogenitas, dan uji t-test.

Kata kunci: sejarah; pedagogi reflektif; sikap kepemimpinan

\section{Pendahuluan}

Rencana penyerdehanaan Kurikulum 2013 yang digagas Kementerian Pendidikan dan Kebudayaan menuai polemik keras dari masyarakat akhir-akhir ini. Hal ini tidak terlepas karena bocornya draft yang didalamnya memuat rumusan akan dihapuskannya mata pelajaran sejarah di jenjang SMK dan menjadikan sejarah menjadi mata pelajaran pilihan di jenjang SMA dari struktur kurikulum nasional. Kritik tajam datang terutama dari organisasi 
profesi seperti Asosiasi Guru Sejarah Indonesia (AGSI), Perkumpulan Prodi Pendidikan Sejarah Se-Indonesia (P3SI), Perkumpulan Prodi Sejarah Se-Indonesia (PPSI), Masyarakat Sejarawan Indonesia (MSI) dan Persatuan Guru Republik Indonesia (PGRI). Selain itu pihakpihak lain pun juga bersuara seperti Ketua MPR, Anggota DPR, hingga KPAI. Fenomena ini sebenarnya menunjukkan bahwa masyarakat memiliki kepedulian dan kesadaran sejarah yang tinggi. Pendidikan sejarah dianggap sebagai instrumen penting dalam pembentukan nilai karakter bangsa terutama peserta didik. Purwanta (2019:43) menjelaskan pendidikan sejarah bertugas menanamkan peserta didik tanggung jawab untuk memajukan kebaikan bersama demi terwujudnya cita-cita masyarakat dan bangsa Indonesia. Peristiwa sejarah yang dibahas tidak hanya diceritakan, tetapi juga digunakan untuk menginspirasi peserta didik untuk meraih kemajuan dan mewujudkan tata nilai hidup ideal.

Presiden AGSI Sumardiansyah Kusuma memberikan pandangan terkait urgensi pembelajaran sejarah bahwa sejarah merupakan pondasi dari semua ilmu humaniora. Mempelajari sejarah sama artinya mempelajari kehidupan, terutama kehidupan manusia ditengah masyarakat dan zamannya. Sebuah bangsa akan menjadi kuat jika memiliki kesadaran sejarah, bagaimana sejarah itu berupaya membentuk bangsa Indonesia menjadi "bangsa-wan", bangsawan yang berdaulat di atas tanah sendiri serta memiliki kemampuan menjalani realitas dan menyelesaikan berbagai tantangan yang dihadapi dengan bercermin atau mengambil pelajaran dari masa lalu. (Kompas, 2/10/2020). Filsuf Francis Bacon pernah merumuskan "histories make man wise". Bahwa sejarah dapat memberikan kebijaksanaan dan kearifan bagi yang mau mempelajarinya. Cicero pun memberikan diktum "historia est testis temporum, lux veritatis, vita memoria, magistra vitae, nuntia vestustatis", bahwa sejarah adalah tanda zaman, cahaya kebenaran, ingatan kehidupan, guru kehidupan, utusan zaman purba; atau sering disingkat sebagai personifikasi sejarah "historia magistra vitae" sejarah ialah guru kehidupan.

Melihat perkembangan kontekstual saat ini ditengah derasnya arus globalisasi yang membuat manusia hidup semakin pongah karena glamour modernitas, individualistik, materialistik dan serba instant. Sejarah merupakan kaca untuk bercermin siapakah kita, darimana kita berasal sebagai pribadi suatu bangsa dengan adab ketimuran yang penuh norma sopan santun, religiusitas, dan nilai-nilai yang luhur. Menjalani masa kini untuk melangkah menuju masa depan tanpa pijakan kearifan masa lalu bagaikan berjalan dengan kaca mata kuda. Berjalan hanya kedepan saja dengan dikendalikan sang kusir. Ibarat suatu bangsa kita tidak dapat berdiri diatas kaki kita sendiri (berdikari). Bangsa kita maju dengan disetir bangsa lain yang lebih kuat. Kita kehilangan jati diri kita sebagai bangsa yang merdeka dan akan terombang ambing, teralienasi dan tidak mampu memaknai eksistensi diri dalam 
gelombang globalisasi yang semakin modern ini. Tepatlah Kartodirdjo (2019) mengatakan jika orang yang tidak mengetahui sejarah dapat diibaratkan seperti sakit jiwa. Mereka kehilangan identitasnya dan karena itu merupakan bahaya bagi masyarakat sekitarnya antara lain karena kelakuannya sudah tidak menentu dan terlepas dari norma-norma atau nilai-nilai hidup yang berlaku di lingkungan itu. Bangsa Indonesia sekarang ini rupanya sedang mengalami krisis identitas nasional. Kita sedang diliputi penyakit "amnesia" lupa sejarah, lupa diri, dan lupa identitas. Martabat dan harga diri tidak menjadi pertimbangan lagi. Hati nurani sudah mati. Orang tidak punya rasa malu untuk berbuat apapun yang sebenarnya tidak lagi pantas. Bahasa kepentingan menjadi segala-galanya. (Daliman, 2018:ix). Krisis identitas nasional yang sedang mendera dalam konteks ini ialah krisis kepemimpinan. Persekongkolan jahat antara para cukong-cukong, oknum pemimpin yang membuat kebijakan serampangan tanpa melihat aspirasi masyarakat, perilaku korup para pejabat dari pusat hingga daerah, budaya kolusi nepotisme menjadi marak seakan hal biasa, hingga karakter menindas yang lemah merupakan sederet masalah kepemimpinan yang memprihatinkan.

Karkono (1983) mengatakan krisis yang sekarang terjadi mengingatkan pada ramalan pujangga Ranggawarsita dalam Serat Kalatidha bait 11 "Sekarang martabat negara, nampak telah sunyi, rusak pelaksanaan peraturan, karena tanpa teladan, kesopanan ditinggalkan, para cendekiawan dan ahli terbawa hanut dalam jaman bimbang, hilang tandatanda manusia, sengsara dunia tergenang petaka". Krisis kepemimpinan yang dialami para elite tersebut karena kehilangan pijakan masa lalu mengenai konsep ideal kepemimpinan yang luhur. Celakanya, krisis ini juga ditiru oleh peserta didik di usia remajanya. Mereka sedang dalam tahap pencarian jati diri. Proses imitasi dan identifikasi pola perilaku sedang berjalan dalam usia-usia remaja. Sayangnya proses ini cenderung meniru pola perilaku para elite yang tiap hari ditampilkan dalam bingkai media massa di era globalisasi. Krisis kepemimpinan pada peserta didik terlihat dengan adanya budaya kurang empati terhadap sesama, tidak menghormati guru dan teman sebaya, tawuran, penyalahgunaan obat terlarang dan miras, budaya copy paste, serta pribadi yang antipati dan pesimistis.

Menurut Lickona (2019) ketika berpikir tentang karakter macam apa yang diinginkan untuk peserta didik, jelaslah bahwa kita ingin agar mereka dapat menilai apa yang benar, dan kemudian melakukan apa yang mereka yakini sebagai sesuatu yang benar, bahkan ketika mereka menghadapi tekanan dari luar dan godaan dari dalam diri mereka sendiri. Pendidikan nilai karakter dapat diintegrasikan dalam pembelajaran sejarah. Apabila dilihat dari filosofi pedagogiknya, pembelajaran sejarah di sekolah memiliki tiga sarana 
penyampaian kompetensi. Transmitting knowledge yaitu terkait kompetensi keilmuan sejarah didalamnya tentang narasi peristiwa sejarah dan fakta-faktanya. Transmitting values terkait dengan nilai-nilai karakter yang dapat dipetik dan hikmah dari belajar sejarah, serta Transmitting virtue terkait keteladanan sejarah yang diwujudkan dalam sikap sehari-hari. Ketiga hal diatas, dapat dikatakan merupakan "fungsi edukatif" dari sejarah. Widja (1988) menjelaskan guna edukatif dari sejarah berarti menyadari makna dari sejarah sebagai masa lampau yang penuh arti, yang selanjutnya berarti memungut dari sejarah berupa nilai-nilai berupa ide-ide maupun konsep-konsep kreatif sebagai sumber motivasi bagi pemecahan masalah-masalah kita masa kini dan selanjutnya untuk merealisir harapan-harapan yang akan datang.

Sehubungan dengan eksplorasi nilai karakter dari pembelajaran sejarah, maka perlu sebuah desain model yang inovatif. Model ini mengakomodir upaya reflektif bagi peserta didik untuk dapat mengambil makna nilai karakter materi sejarah yang dipelajari. Maka dari itu, Guru dituntut dapat mengembangkan desain model pembelajaran yang out of the box, dan diluar pakem. Tidak berkutat pada guru berbicara, murid mendengarkan. Tidak berkutat hanya pada diktat-diktat. Leo Agung (2015) menjelaskan jika pembelajaran sejarah selama ini masih berkutat pada diktat-diktat sehingga guru kesulitan untuk berinovasi. Selaras dengan itu, Sayono (2013) menyatakan bahwa hal ini berkaitan dengan sikap pragmatis dan pasif guru sehingga kurang memberikan inspirasi kepada peserta didik melalui mata pelajaran sejarah yang diajarkan. Pada sisi yang lain, Said Hasan menuturkan bahwa guru sejarah harus mampu menyadari dari apa yang diajarkan, bisa mengembangkan kreatifitas anak didik, bagaimana mereka bisa menyelesaikan masalah sebagaimana teladan para pahlawan. Pembelajaran sejarah memang harus berubah, kita harus ajarkan jiwa kejuangan, jiwa inovatif. Kalau hanya mengajarkan fakta, itu hanya mengajarkan abu sejarah. (Kompas, 2020).

Apabila desain model pembelajaran sejarah telah mampu mengakomodir upaya refleksi nilai-nilai karakter, maka sejarah akan membentuk kemanusiaan kita dan untuk mengenal siapa kita serta kearah mana kita akan menghadapi masa depan. (Wiriaatmadja, 2016, Wineburg, 2001, Tosh, 1984, Dickinson and Lee, 1980). Berangkat dari latar permasalahan diatas dan hasil observasi penelitian di lapangan diketemukan beberapa problematika diantaranya 1) perlunya dikembangkan sikap kepemimpinan peserta didik 2) guru masih berkutat pada diktat-diktat 3) perlunya dikembangkan model pembelajaran baru yang berbasis pedagogi reflektif. Pedagogi reflektif sendiri merupakan sebuah pendekatan dalam pembelajaran yang mengintegrasikan pembelajaran bidang studi dengan nilai-nilai karakter (Subagya, 2010). Pedagogi ini menekankan pada pendidikan yang holistik. Peserta 
didik dituntut bukan hanya cerdas secara pengetahuan, tetapi memiliki nilai-nilai yang luhur, peka terhadap sesama, dan tindakan bagi sesama. (Suparno, 2015). Beberapa penelitian terdahulu memperlihatkan apabila pendekatan pedagogi reflektif cukup mampu menyajikan pembelajaran sejarah yang bermakna. Pembelajaran sejarah yang menggali nilai karakter dari tiap materi yang dipelajari peseta didik. (Printina, 2017, 2019, Utami 2019). Berdasarkan latar belakang yang telah diuraikan diatas, maka penelitian ini mengembangkan model pembelajaran sejarah kepemimpinan berbasis pedagogi reflektif untuk meningkatkan sikap kepemimpinan siswa SMA. Penelitian pengembangan model ini diambil dari problem based learning dengan menggunakan pendekatan pedagogi reflektif. Adapun kompetensi dasar (KD) yang digunakan K.D 3.2 dengan sub materi tentang heroisme RM Said atau Mangkunegara I di Kelas XI IPS.

\section{Metode}

Penelitian ini dirancang dengan pendekatan penelitian pengembangan. Model pengembangan yang digunakan ialah model pengembangan Borg and Gall (2003) yang disederhanakan Nana Syaodih Sukmadinata menjadi tiga langkah. Langkah-langkah tersebut oleh Sukmadinata (2012) yaitu: (1) tahap studi pendahuluan; (2) tahap pengembangan model; (3) tahap uji model atau evaluasi.

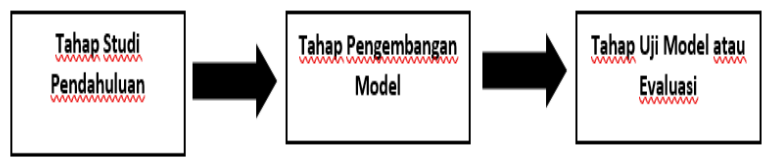

Gambar 1. Langkah Sukmadinata, 2012

Tahap pendahuluan dalam penelitian ini yaitu melihat kondisi pembelajaran dan sikap kepemimpinan peserta didik. Tahap pengembangan model meliputi merancang draft model dan validasi ahli. Tahap uji model dalam penelitian ini untuk mengetahui efektifitas model pembelajaran yang telah dirancang. Teknik pengumpulan data melalui observasi pembelajaran di kelas, wawancara dengan guru sejarah, angket, dan evaluasi post test. Sedangkan objek penelitian pengembangan model pembelajaran sejarah yaitu peserta didik kelas XI IPS SMA Kolese De Britto, Kota Yogyakarta. Kelas IPS dipilih karena memiliki jumlah jam pelajaran sejarah yang lebih banyak jika dibandingkan kelas IPA maupun Bahasa. Alasan lainnya karena K.D 3.2 dengan sub materi tentang heroisme RM. Said ada di kelas XI IPS. Serta dikelas IPS ini merupakan kelas sosial yang diharapkan kelak lahir para alumni yang menjadi pemimpin masa depan sehingga perlu dibekali materi nilai-nilai kepemimpinan. Terkait uji efektifitas model pembelajaran sejarah terhadap peningkatan sikap kepemimpinan peserta didik, maka diadakan post test terhadap dua kelas yaitu kelas 
kontrol di XI IPS 1 dan kelas eksperimen di XI IPS 2. Uji normalitas menggunakan program SPSS 23 yaitu Kolmogorov Smirnov. Tujuannya untuk mengetahui apakah populasi memiliki distribusi normal. Sedangkan uji lainnya meliputi uji homogenitas yaitu uji Test of Homogenity of Variances. Serta uji t yaitu uji Independent Sample test.

\section{Hasil Dan Pembahasan}

\section{Kondisi Awal Sikap Kepemimpinan Peserta Didik}

Analisis awal mengenai sikap kepemimpinan dilaksanakan dengan wawancara guru sejarah dan observasi kelas untuk melihat sejauh mana nilai karakter kepemimpinan peserta didik. Ada delapan indikator sikap kepemimpinan yang diambil dari teori kepemimpinan Ignatian (2019) dan teori kepemimpinan umum Northouse (2013). Pertama, kesadaran diri. Indikator kesadaran diri adalah pemahaman mengenai diri sendiri secara mendalam. Unsur-unsur dari dalam diri yang perlu diketahui adalah kekuatan, kelemahan, pandangan dan visi hidup. Kesadaran akan unsur-unsur ini syarat mutlak dalam kepemimpinan. Menurut guru sejarah, pada umumnya peserta didik masih belum mempunyai kesadaran diri yang baik. Masih banyak peserta didik yang tidak sadar akan tanggung jawabnya sebagai kaum terpelajar. Pandangan hidup untuk meraih cita-cita ke depan masih abstrak. Hal-hal seperti tidak aktif dalam pembelajaran sejarah, lupa mengerjakan tugas sekolah, telat masuk kelas merupakan unsur kesadaran diri yang masih rendah.

Kedua, ingenuitas merupakan kekuatan berinovasi dan adaptasi sehingga tetap dapat maju dalam dunia yang terus berubah. Ingenuitas merupakan unsur kepemimpinan yang dibutuhkan zaman ini karena adanya perubahan mendasar pada setiap aspek kehidupan manusia. Berdasarkan observasi kelas saat pembelajaran sejarah, peserta didik terlihat mampu berinovasi dengan baik. Era teknologi dizaman globalisasi ini peserta didik mampu mengeksplorasi materi-materi dari dunia maya. Namun masih ada peserta didik menyalah gunakan untuk hal-hal lain misal bermain game online yang tentu menjadi candu. Pendampingan guru sangat penting untuk mengarahkan inovasi peserta didik ke arah yang benar.Ketiga, cinta kasih menjadi bagian terpenting dalam unsur kepemimpinan. Cinta kasih merupakan kekuatan untu merealisasikan kehidupan bersama yang damai, adil dan sejahtera. Cinta kasih terwujud dalam tindakan saling menghargai, mendukung dan menghargai satu sama lainnya. Kehidupan globalisasi yang menuntut persaingan yang individualistik membuat peserta didik acuh tak acuh dan soliter. Dalam kerja kelompok terlihat ada peserta didik yang tidak bisa bergabung dengan teman kelompoknya. Persentasi kelompok apabila ada pendapat yang dirasa kurang benar, kelompok lainnya melakukan 
bullying. Keempat, heroisme merupakan keberanian untuk melakukan sesuatu yang dianggap benar dan gigih memperjuangkan. Heroisme merupakan indikator utama dalam sikap kepemimpinan. Semangat heroik seorang pemimpin biasanya akan memantik orang lain untuk bergerak bersama. Dinamika pembelajaran sejarah masih banyak peserta didik yang kurang aktif. Masih ada yang malu-malu atau takut untuk sekedar bertanya dan menyampaikan pendapatnya. Bahkan ketika guru mempersilahkan peserta didik bertanya, banyak yang terdiam tidak berani mengemukakan pendapatnya meskipun salah pun tidak dilarang. Kelima, kecerdasan merupakan basic kemampuan yang harus dimiliki dalam kepemimpinan. Seseorang yang memiliki sikap kepemimpinan yang baik biasanya cerdas secara intelektual dan cerdas secara sosial. Selain itu memiliki kemampuan verbal, membuat persepsi dan analisis yang dalam. Dalam pembelajaran sejarah yang cenderung textbook pada satu diktat bahan belajar saja membuat peserta didik kurang memiliki analisis sejarah yang dalam. Pada masa sekarang yang canggih, peserta didik mencari jalan pintas dengan mencari sumber-sumber internet yang memiliki kredibilitas kebenaran ilmu sejarah yang rendah.

Keenam, keyakinan diri menjadi indikator kepemimpinan agar seorang pemimpin yakin akan kemampuan diri yang dimilikinya. Keyakinan diri juga mencakup keyakinan atas keterampilan sendiri dan yakin dapat membuat perubahan. Peserta didik sebagai calon penerus bangsa harus diberikan motivasi oleh guru agar merasa yakin akan kemampuannya. Masih banyak peserta didik yang tidak yakin dengan dirinya sendiri, dilihat dari kurang yakin saat berpendapat, buah pikirannya dan kurang bisa melihat keunggulan dari dalam dirinya. Ketujuh, ketekunan merupakan hasrat untuk menyelesaikan pekerjaan mencakup karakteristik inisiatif, keuletan dan dominasi. Ketekunan akan memaksa pemimpin untuk proaktif dan memiliki ketahanan saat menyelesaikan suatu permasalahan. Peserta didik dalam proses pembelajaran masih terlihat kurang tekun. Dalam pembelajaran masih terlihat kurang fokus dan suka mengobrol dengan teman-temannya.

Kedelapan, integritas adalah karakter penting dalam kepemimpinan. Integritas merupakan karakter kejujuran dan keterandalan. Pada dasarnya seseorang yang memiliki integritas layak untuk dipercaya dan layak mendapatkan kepercayaan. Budaya integritas penting dalam dunia pendidikan. Peserta didik masih sering dalam mengerjakan tugas menggunakan proses yang instan yaitu copy paste dari internet, bisa disebut plagiarisme. Kesembilan, kemampuan bersosialisasi merupkan kecenderungan sesorang pemimpin untuk menjalin relasi dengan baik. Pemimpin harus menciptakan relasi yang kooperatif seperti ramah, sopan, dan terbuka. Berdasarkan hasil observasi kelas masih terlihat ada beberapa 
peserta didik yang kurang kooperatif ketika diajak berdiskusi. Beberapa masih menunjukan sikap yang diam dan kurang aktif. Uraian di atas menunjukkan bahwa sikap kepemimpinan di kalangan peserta didik masih rendah, karena itu perlu upaya untuk memperbaikinya. Guru dapat menanamkan nilai kepemimpinan dengan mengintegrasikan nilai karakter dalam pembelajaran sejarah. Dalam penelitian ini disarankan mendesain model pembelajaran sejarah kepemimpinan berbasis pedagogi reflektif.

\section{Kebutuhan Pengembangan Model}

Selama observasi dilakukan terlihat guru masih kurang dalam mengelola pembelajaran dan mendesain model. Hal ini tercermin dari: (1) guru masih terpaku diktatdiktat materi; (2) guru masih mendominasi pembelajaran, teacher oriented; (3) masih menekankan pada aspek pengetahuan kesejaharahan saja; (4) belum mengintegrasikan nilainilai kepemimpinan dalam pembelajaran sejarah; (5) belum dikembangkannya model pembelajaran sejarah dengan pedagogi reflektif. Ada beberapa hal yang menyebabkan guru tersandera pada pola-pola pengajaran yang masih konvensional. Dalam sesi wawancara dengan guru sejarah menyebutkan bahwa alokasi jam pelajaran yang dinilai cukup kurang apabila dibandingkan dengan materi yang sangat padat menjadi penyebab yang utama. Guru sejarah mengharapkan adanya sebuah desain model pembelajaran yang inovatif, setidaknya untuk dua hal yaitu pertama, agar pembelajaran lebih hidup dan kedua, model tersebut dapat mengeksplorasi aspek nilai karakter khususnya kepemimpinan dalam pembelajaran.

Hasil wawancara mengalir dengan dua orang guru sejarah menunjukan hasil yang positif terhadap pengembangan model pembelajaran sejarah. Seperti pendapat Dimas bahwa "perlu di desain sebuah model agar peserta didik tidak bosan, dan dapat meningkatkan daya juang". Selaras dengan itu guru sejarah lainnya, Rio mengatakan "perlu dikembangkan sebuah model yang memberikan tempat bagi peserta didik untuk berdiskusi sebagai upaya penghayatan nilai dari materi yang dipelajari”. Hasil penyebaran angket tentang kebutuhan pengembangan model pembelajaran juga menunjukan hasil positif terhadap kebutuhan desain model. Angket awal disebar terhadap 70 peserta didik dari kelas XI IPS 1, XI IPS 2 dan XI IPS 3. Hasil menunjukan jika sebanyak 63 peserta didik (90\%) membutuhkan model pembelajaran sejarah kepemimpinan yang berbasis pedagogi reflektif.

\section{Hasil Pengembangan Draft Model}

Berdasarkan uraian serta temuan pada analisis pendahuluan maka pada tahap pengembangan model ini untuk merancang draft model pembelajaran dan mengetahui masukan validasi dari pakar ahli. Pada tahap pengembangan model ini menghasilkan perangkat pembelajaran. Perangkat meliputi semua bahan-bahan yang dibutuhkan untuk pelaksanaan model pembelajaran seperti Draft model pembelajaran, Sintak Pembelajaran, 
RPP, dan bahan materi berupa handout. Draft model pembelajaran sejarah kepemimpinan ini merupakan hasil pengembangan peneliti yang dikembangkan dari model problem based learning yang didekati dengan pendekatan pedagogi reflektif. Langkah-langkah pembelajaran dalam draft model ini disusun secara sistematik dan rinci. Secara garis besar terdapat lima langkah pembelajaran. Terdapat rincian kegiatan apa yang harus dilakukan guru sebagai pendidik maupun peserta didik sebagai pembelajar. Seluruh kegiatan dalam model ini harus dijalankan dengan runtut agar tercapai tujuan instruksionalnya. Tujuan pembelajaran ini terdapat 6 yaitu competence, conscience, compassion, commitment, consistency, dan leadership. Draft model pembelajaran sejarah ini diberi nama model KMNPPR, dapat dilihat pada gambar II berikut :
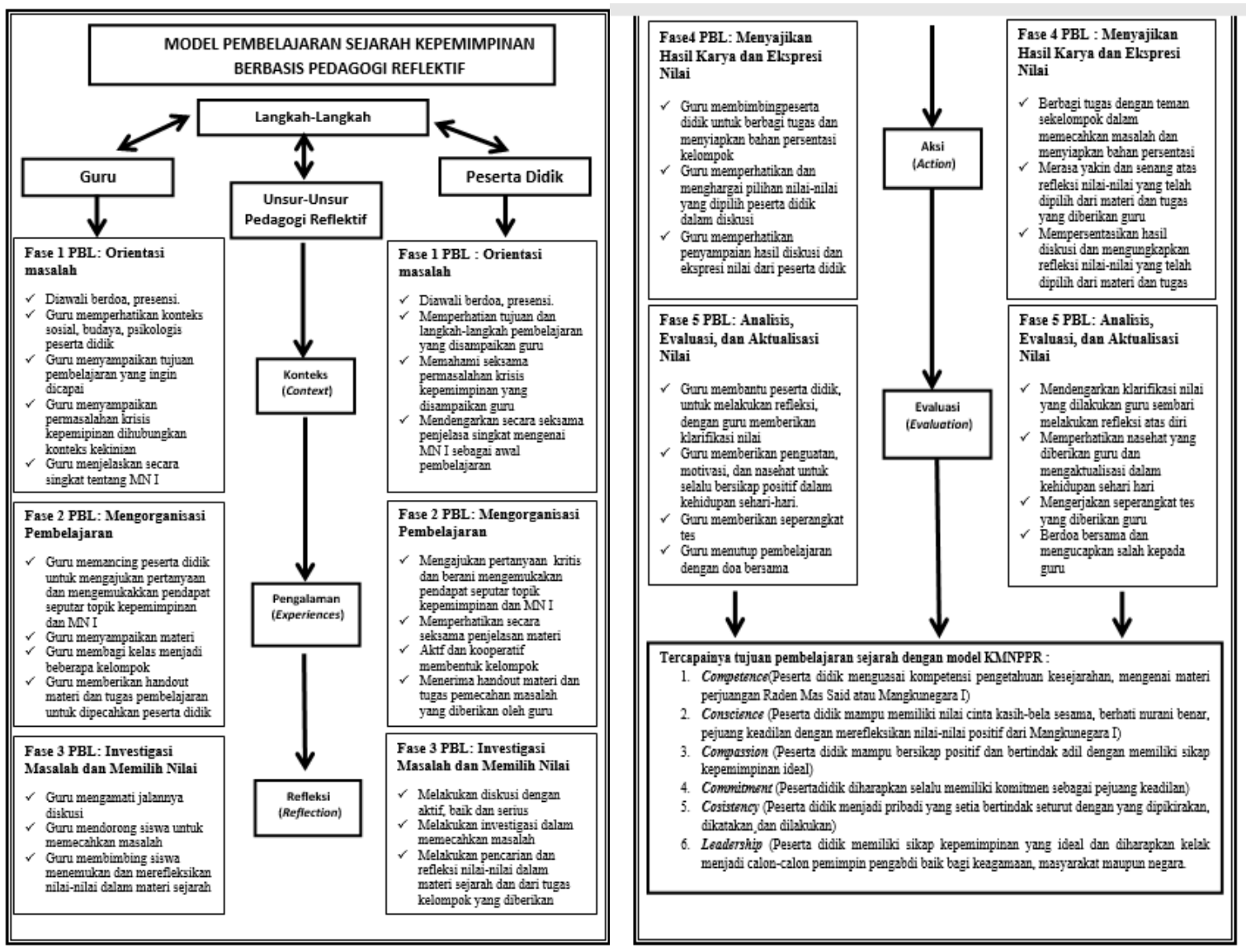

Gambar 2. Draft Model Pembelajaran Sejarah Kepemimpinan 


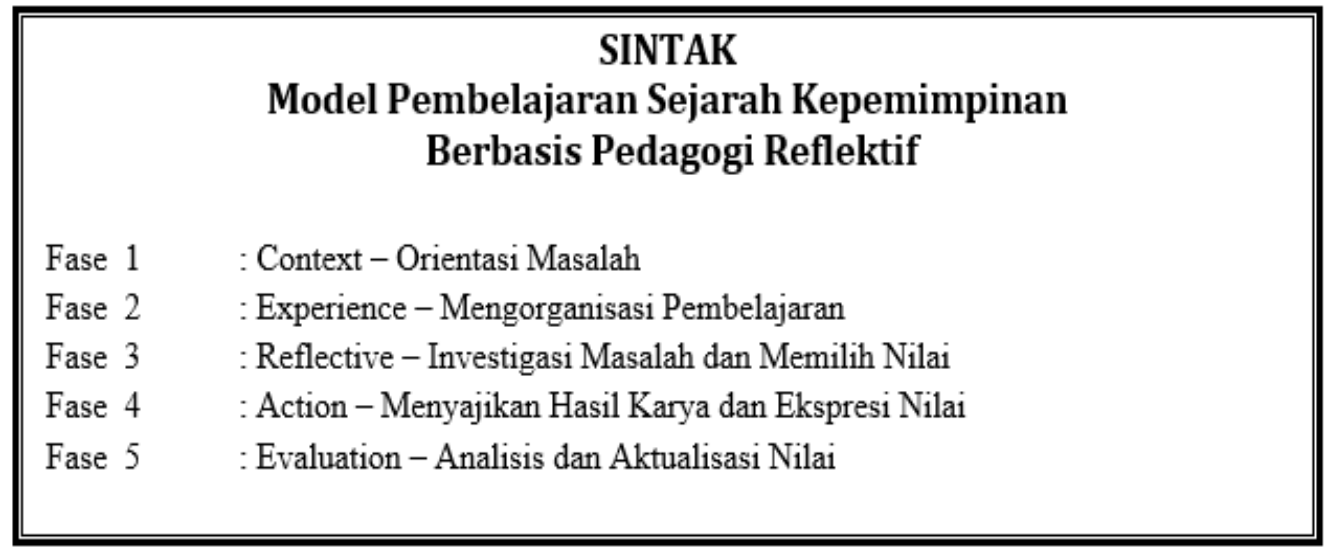

\section{Gambar 3. Sintak Model Pembelajaran Sejarah Kepemimpinan}

Sintak merupakan fase atau tahap kegiatan dalam pembelajaran. Sintak pada gambar III merupakan hasil pengembangan dalam penelitian ini yang dikembangkan dari model problem based learning yang dipadukan dengan pendekatan pedagogi reflektif. Secara garis besar ada lima fase yang apabila dijabarkan ada langkah-langkah yang harus dilakukan guru dan peserta didik. Fase 1 : Context (Dinamika Orientasi Masalah). Langkah-langkah yang dilakukan guru mengawali dengan berdoa dan presensi, melakukan manajemen kelas dengan memeperhatikan konteks sosio kultural peserta didik, menyampaikan tujuan pembelajaran yang ingin dicapai, melakukan apersepsi secara konteksual mengenai krisis kepemimpinan saat ini, menerangkan secara singkat materi perjuangan Raden Mas Said. Fase 2: Experience (Mengorganisasikan Pembelajaran). Langkah-langkah yang dilakukan merangsang peserta didik untuk bertanya tentang materi yang sudah disampaikan singkat di apersepsi, guru menyampaikan materi secara lebih rinci namun padat, membagi peserta didik dalam kelompok diskusi, membagikan handout yang dikembangkan dan memberikan suatu tugas permasalahan untuk dipecahkan.

Fase 3 : Reflective (Investigasi masalah dan memilih nilai). Langkah-langkah yang dilakukan yaitu guru mengawasi jalannya diskusi kelompok, menjadi fasilitator dan mendorong peserta didik memecahkan permasalahan, membantu peserta didik untuk dapat merefleksikan nilai-nilai karakter kepemimpinan dari materi perjuangan Raden Mas Said. Fase 4 : Action (Menyajikan hasil karya dan ekspresi nilai). Langkah-langkah yang dilaksanakan meliputi membimbing persta didik untuk menyiapkan bahan persentasi atas hasil diskusi kelompoknya, memberikan pujian terhadap hasil karya peserta didik, kelompok yang maju mempersentasikan hasil diskusinya dan berani berpendapat menyampaikan hasil refleksi nilai-nilai kepemimpinan yang didapatnya dari materi. Fase 5 : Evaluation (Analisis dan Aktualisasi Nilai). Langkah-langkahnya yaitu guru memberikan klarifikasi nilai atas 
pembelajaran yang telah dilalui bersama, memberikan motivasi dan penguatan kepada peseta didik, lalu memberikan seperangkat tes terutama angket afeksi sikap kepemimpinan, dan yang terakhir menutup pertemuan dengan berdoa bersama. Setelah perangkat model selesai dirancang, maka selanjutkan dilakukan validasi pakar. Perangkat model yang dinilai oleh validator meliputi draft model, sintak pembelajaran, RPP, dan handout materi sejarah. Ahli model pembelajaran yang melakukan validasi adalah Prof. Dr. Nunuk Suryani (Guru Besar Teknologi Pembelajaran Sejarah UNS), Prof. Dr. Leo Agung S (Guru Besar Pendidikan Sejarah UNS), Dr. Cicilia Dyah S (Dosen Ilmu Pendidikan UNS).

Berdasarkan hasil uji validitas para pakar diperoleh penilaian, diantaranya aspekaspek draft model dan sintak pembelajaran memperoleh skor 3,8 termasuk kategori sangat baik oleh Prof Nunuk. Aspek-aspek dalam RPP memperoleh skor 3,9 yang juga termasuk kategori sangat baik oleh Dr. Cicilia. Aspek-aspek materi dalam handout memperoleh skor rata-rata 3,4 yang juga termasuk sangat baik oleh Prof. Leo Agung. Rentang penilaian yang digunakan menggunakan skala likert 1 sampai 4. Hasil penilaian validasi para ahli menunjukkan apabila model pembelajaran sejarah yang dikembangkan layak untuk digunakan dalam pembelajaran.

\section{Uji Efektifitas Model Pembelajaran}

Efektifitas pengembangan model pembelajaran sejarah kepemimpinan berbasis pedagogi reflektif terbukti sangat efektif untuk meningkatkan sikap kepemimpinan peserta didik setelah dilakukan uji normalitas, uji homogenitas, dan uji hipotesis.

One-Sample Kolmogorov-Smirnov Test

\begin{tabular}{|c|c|c|}
\hline & Posttest_Ek & Posttest_Kon \\
\hline N & 28 & 28 \\
Test Statistic & .109 & .121 \\
Asymp. Sig. (2-tailed) & $.200^{c, d}$ & $.200^{c, d}$ \\
\hline
\end{tabular}

Gambar 4. Hasil Uji Normalitas

Uji normalitas digunakan untuk melihat apakah data yang digunakan berdistribusi normal atau tidak. Data dikatakan normal jika memiliki probabilitas lebih dari 0,05. Melihat hasil uji SPSS yang ditampilkan di gambar IV diatas, diperoleh nilai signifikansi 0,200 untuk kelas eksperimen dan nilai 0,200 untuk kelas kontrol. Maka dapat ditarik kesimpulan jika data dalam keadaan normal karena antara kelas eksperimen dan kontrol >0,05. 
Test of Homogeneity of Variances

Postest Skor

\begin{tabular}{|c|c|c|c|}
\hline Levene Statistic & df1 & df2 & Sig. \\
\hline 2,055 & 7 & 11 & .137 \\
\hline
\end{tabular}

Gambar 5. Hasil Uji Homogenitas

Uji homogenitas untuk mengetahui apakah populasi berasal dari varians yang sama. Berdasarkan hasil SPSS pada gambar V diatas diperoleh nilai signifikansi 0,137. Maka dapat disimpulkan bahwa hasil antara kelas eksperimen dan control ialah sama karena > 0,05 .

Uji t-Test

\begin{tabular}{|c|c|c|c|c|}
\hline \multicolumn{2}{|c|}{ Mean } & t & df & Sig. (2-tailed) \\
\cline { 1 - 2 } Eks & Kon & & & \\
\hline 74,07 & 65,21 & $-6,774$ & 54 &, 000 \\
& & & & \\
\hline
\end{tabular}

Gambar 6. Hasil Uji Efektivitas

Berdasarkan uji efektifitas SPSS yang ditunjukan gambar VI diatas diketahui bahwa posttest kelas eksperimen 74,07 sedangkan rerata kelas control 65,21. Adapun t sebesar 6,774 dengan taraf signifikansi 0,000. Dapat disimpulkan bahwa Ho ditolak dan HI diterima, yakni karena 0,000 lebih kecil dari 0,05 artinya terdapat perbedaan rerata antara kelas eksperimen dan kontrol dari sikap kepemimpinan, dimana rerata kelas eksperimen diberikan tindakan. Berdasarkan ketiga hasil uji diatas maka dapat disimpulkan bahwa model pembelajaran sejarah kepemimpinan berbasis pedagogi reflektif efektif untuk meningkatkan sikap kepemimpinan siswa SMA.

\section{Pembahasan}

Pendidikan merupakan proses pembudayaan (Tilaar, 2009: 30). Pembudayaan nilai karakter luhur kepada peserta didik untuk bekal masa depannya. Apabila mengacu UU No 20 Tahun 2003 tentang Sisdiknas bahwa pendidikan nasional berfungsi untuk mengembangkan kemampuan dan membentuk watak serta peradaban bangsa yang bermartabat dalam rangka mencerdaskan kehidupan bangsa. Pendidikan sendiri bertujuan mengembangkan potensi peserta didik agar menjadi manusia yang beriman dan bertaqwa kepada Tuhan Yang Maha Esa, berakhlak mulia, sehat, berilmu, cakap, kreatif, mandiri, dan menjadi warga negara yang demokratis, serta bertanggung jawab. Fokus penelitian pengembangan di SMA De Britto, Yogyakarta merupakan sekolah yang membudayakan nilai kepemimpinan. Pendidikan di SMA De Britto diarahkan untuk membentuk peserta didik menjadi pemimpin pengabdi 
(leader of service) yang kompeten (competence), berhati nurani besar (conscience), berbela rasa (compassion), berkomitmen sebagai pejuang keadilan (commitment), dan konsisten (consistency). Kepemimpinan diartikan sebagai kemampuan seseorang untuk mempengaruhi orang lain (Soekanto, 2002:288). Pada dasarnya kepemimpinan didasari sifat terpuji, laku bijak, serta sikap tanggung jawab, dan ketercerahan tentang tujuan hidup yang luhur dan visi yang ditujukan untuk kemaslahatan hidup bermasyarakat (Pabotinggi, 2013). Pada penelitian ini untuk melihat sikap kepemimpinan peserta didik menggunakan 8 indikator kepemimpinan dari 2 teori yaitu milik Northouse (meliputi kecerdasan, keyakinan diri, ketekunan, integritas); dan milik Ignatian (meliputi kesadaran diri, ingenuitas, cinta kasih, dan heroisme). Berdasarkan analisis observasi pembelajaran, angket dan wawancara dengan guru sejarah didapati kesimpulan jika perlu ditingkatkan sikap kepemimpinan peserta didik, dan perlu dikembangkan sebuah desain model pembelajaran yang menekankan sisi afektif selain sisi pengetahuan.

Pedagogi reflektif merupakan pendekatan pembelajaran khas di sekolah-sekolah Jesuit yang cocok untuk mengembangkan desain tersebut. Penelitian-penelitian terdahulu tentang pedagogi reflektif dalam pembelajaran sejarah dapat dilihat dari penelitian Printina (2019) tentang pengembangan media komik digital dengan pendekatan pedagogi reflektif pada mata kuliah sejarah asia barat modern. Penelitian lainnya milik Utami (2019) tentang pengajaran empati sejarah yang menggunakan pembelajaran reflektif. Pedagogi reflektif memberikan cara pandang baru dalam memahami pembelajaran sejarah dikelas. Belajar sejarah tidak hanya terkesan hafalan-hafalan semata mengenai narasi cerita sejarah tetapi juga ada nilai karakter yang dapat dipetik dari narasi yang dipelajari. Menurut Suparno (2015: 6) Pedagogi reflektif merupakan pedagogi yang membantu kebutuhan pendidikan yang utuh dan menyeluruh (holistik). Peserta didik dibantu berkembang bukan hanya menguasai bidang keahliannya, namun juga mampu mengembangkan suara hati, kehendak baik, dan terutama kesadaran sosialnya untuk berpikir dan bertindak bagi orang lain dan bangsanya. Pendek kata hidup bersama orang lain dan bagi orang lain "man for and with others". Pedagogi reflektif menekankan pada upaya berfikir reflektif dan kontempelasi dari tiap materi dalam kegiatan pembelajaran. Berfikir reflektif merupakan jembatan penghubung antara pemahaman kognitif dan internalisasi nilai. Hal ini selaras dari filosofis pembelajaran sejarah disekolah untuk mengajarkan nilai-nilai dari sejarah masa lampau. 


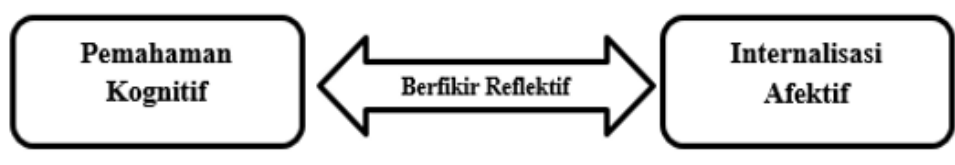

Gambar 7. Berpikir kritis

Materi tentang perjuangan RM Said atau Mangkunegara I dipilih karena terdapat pada materi KD 3.2 di kelas XI IPS. RM Said juga ditetapkan menjadi Pahlawan Nasional tahun 1983. Tokoh RM Said sendiri merupakan seorang tokoh pemimpin jawa yang heroik. RM Said dengan gagah berani melawan VOC dan para penguasa saat itu yang dianggap lalim. Bersama pasukannya, ia mengikrarkan semangat Tiji-Tibeh (mati siji mati kabeh, mukti siji mukti kabeh), diartikan mati satu mati semua, berjaya satu berjaya semua. Selain itu juga semboyan Tridharma rumangsa melu handarbeni, wajib melu hanggodeli/hangrungkebi, dan mulat sarira hangrasa wani. Nilai karakter kejuangannya dapat diajarkan kepada peserta didik untuk menumbuhkan nilai-nilai kepemimpinan. Pengembangan produk desain model pembelajaran sejarah dalam penelitian ini memadukan antara model problem based learning, pendekatan pedagogi reflektif, dan materi perjuangan RM Said atau Mangkunegara I. Setelah diterapkan dalam pembelajaran dikelas, dapat diketahui hasil dimana sangat efektif untuk meningkatkan sikap kepemimpinan peserta didik. Produk Model pembelajaran ini dapat dipergunakan secara luas untuk tujuan-tujuan pembelajaran afektif. Untuk materi sejarah dapat disesuaikan dengan materi lainnya yang ada di Kompetensi Dasar.

\section{Kesimpulan}

Kesimpulannya bahwa pengembangan model pembelajaran sejarah kepemimpinan berbasis pendekatan pedagogi reflektif sangat efektif untuk meningkatkan sikap kepemimpinan peserta didik. Hal ini dapat dilihat dari hasil uji efektifitas di kelas eksperimen 74,07 dan kelas kontrol 65,21. Adapun untuk Uji T, diperoleh nilai t sebesar 6,774 dengan taraf signifikansi 0,000. Maka dapat disimpulkan bahwa Ho ditolak dan HI diterima, yakni karena 0,000 lebih kecil dari 0,05 artinya terdapat perbedaan rerata antara kelas eksperimen dengan kelas kontrol dalam hal sikap kepemimpinan, dimana kelas eksperimen yang diberi tindakan. Secara umum dapat disimpulkan bahwa terjadi peningkatan sikap kepemimpinan peserta didik.

Implikasi dari penelitian pengembangan model ini yaitu langkah-langkah model pembelajaran ini dapat digunakan guru untuk diterapkan di kelas sejarah. Pembelajaran tidak lagi berkutat pada narasi pengetahuan sejarah saja, namun juga memiliki dampak pengiring afektif yaitu nilai karakter kepemimpinan. Masa yang akan datang diharapkan 
lebih banyak lagi peneliti yang mengembangkan model-model yang menekankan aspek afektif bagi pembelajaran sejarah.

\section{Daftar Pustaka}

Borg, WR and MD, Gall. (2003). Educational Reaserch; An Intoduction, 7th Edition. Boston: Allyn \& Bacon

Daliman. (2018). Manusia dan Sejarah. Yogyakarta: Ombak

Dickinson, A.K., and Lee, P.J. (1980). History Teaching and History Understanding. London: Heinemann

Hasan, Said Hamid. (2020). Pelajaran Sejarah Terancam Hilang. September 18, 2020, HIm 5, Koran Kompas

Karkono, H, Partokusumo. (1983). Zaman Edan. Yogyakarta: Proyek Javanologi

Kartodirdjo, Sartono. (2017). Pendekatan Ilmu Sosial Dalam Metodologi Sejarah. Yogyakarta: Ombak

Kusuma, Sumardianyah P. (2020). Urgensi Mata Pelajaran Sejarah. Oktober 2, 2020, Hlm 6, Koran Kompas

Lickona, Thomas. (2019). Educating For Character: Mendidik Untuk Membentuk Karakter. Jakarta: Bumi Aksara

Northouse, Peter G. (2013). Kepemimpinan: Teori dan Praktik. Terj. Ati Cahayani. Jakarta: Indeks Permata Putri

Pabottingi, M. (2013). Kepemimpinan dan Demokrasi Kita: Akar-akar Kebangkrutan dan Jalan Menuju Kebangkitan. Prisma, Vol. 4, Hlm. 3-27

Printina, Brigida Intan. (2017). Implementasi Pedagogi Reflektif Pada Pembelajaran Sejarah Melalui Media Komik Untuk Membangun Humanisme Dalam Kemajemukan (Book Chapter). Kapita Selekta Pendidikan Sejarah Indonesia. Yogyakarta: Ombak

Printina, Brigida Intan. (2019). Pemanfaatan Media Komik Digital Melalui Paradigma Pedagogi Reflektif Melalui Mata Kuliah Sejarah Asia Barat Modern. Jurnal Pendidikan Sejarah, 8 (1), 1-13, https://doi.org/10.21009/JPS.081.01

Purwanta, Hieronymus. (2019). Hakekat Pendidikan Sejarah. Surakarta: UNS Press

Sayono, Joko. (2013). Pembelajaran Sejarah Di Sekolah: Dari Pragmatis ke Idealis. Jurnal Sejarah dan Budaya, 7 (1), 9-17, http://dx.doi.org/10.17977/sb.v7i1.4733

Soekanto, Soerjono. (2002). Sosiologi Suatu Pengantar. Jakarta: Rajagrafindo Persada

Subagya. (2010). Paradigma Pedagogi Reflektif. Yogyakarta: Kanisius

Sukmadinata, Nana Syaodih. (2012). Metode Penelitian Pendidikan. Bandung: Rosdakarya

Suparno, Paul. (2015). Pembelajaran di Perguruan Tinggi Bergaya Paradigma Pedagogi Refleksi (PPR). Yogyakarta: Penerbit USD

Sutimin, Leo Agung. (2015). The Role of Social Studies And History Learning In Junior High School In Strengthening The Students Character. Paramita, 25 (2), 238-246, https://doi.org/10.15294/paramita.v25i2.5134

Tilaar, HAR. (2009). Membenahi Pendidikan Nasional. Jakarta: Rineka Cipta

Tim Ignatian. (2017). Standar Mutu Pendidikan Sekolah Yesuit. Jakarta: Asosiasi Sekolah Yesuit Indonesia

Tosh, John. (1984). The Persuit of History. London: Longman

Utami, Indah Wahyu Puji. (2019). Teaching Historical Emphaty Trought Reflective Learning. Paramita, 29 (1), 1-9, https://doi.org/10.15294/param (Borg \& MD, 2003)ita.v29i1.11479

Widja, I Gede. (1988). Pengantar Ilmu Sejarah: Sejarah Dalam Perspektif Pendidikan. Semarang: Satya Wacana

Wineburg, Sam. (2001). Historical Thinking. Philadelphia: Temple University Press

Wiriaatmadja, Rochiati. (2016). Filosofi Pendidikan Sejarah. Bandung: Diktat Kuliah. 